\title{
Nitrogen and potassium fertilization on the yield and intensity of the maize white $\operatorname{spot}^{1}$
}

\author{
Gabriel Avelar Dornelas ${ }^{* 2}$, Edson Ampélio Pozza $a^{3}$ Paulo Estevão de Souza ${ }^{3}$, Rodrigo Véras da Costa \\ Adélia Aziz Alexandre Pozza $a^{5}$ Leandro Alvarenga Santos ${ }^{6}$ \\ http://dx.doi.org/10.1590/0034-737X201562040004
}

\begin{abstract}
A plant's nutritional balance can influence its resistance to diseases. In order to evaluate the effect of increasing doses of $\mathrm{N}$ and $\mathrm{K}$ on the yield and severity of the maize white spot, two experiments were installed in the field, one in the city of Ijaci, Minas Gerais, and the other in the city of Sete Lagoas, Minas Gerais. The experimental delimitation was in randomized blocks with $5 \times 5$ factorial analysis of variance, and four repetitions. The treatments consisted of five doses of $\mathrm{N}\left(20 ; 40 ; 80 ; 150 ; 190 \mathrm{Kg} \mathrm{ha}^{-1}\right.$ of $\mathrm{N}$ in the experiments 1 and 2$)$ and five doses of $\mathrm{K}(15 ; 30 ; 60 ; 120$; $180 \mathrm{Kg} \mathrm{ha}^{-1}$ of $\mathrm{K}$ in experiment 1 and 8.75; 17.5; 35; 50; $100 \mathrm{Kg} \mathrm{ha}^{-1}$ of $\mathrm{K}$ in experiment 2). The susceptible cultivar 30P70 was planted in both experiments. The plot consisted of four rows 5 meters long, with a useful area consisting of two central rows 3 meters each. Evaluations began 43 days after emergence (DAE) in the first experiment and 56 DAE in the second one. There was no significant interaction between doses of $\mathrm{N}$ and $\mathrm{K}$ and the disease progress. The effect was only observed for $\mathrm{N}$. The $\mathrm{K}$ did not influence the yield and the severity of the disease in these experiments. Bigger areas below the severity progress curve of the white spot and better yield were observed with increasing doses of $\mathrm{N}$. Thus, with increasing doses of $\mathrm{N}$, the white spot increased and also did the yield.
\end{abstract}

Keywords: Nutritional stress, Zea mays L., foliar diseases.

\section{RESUMO}

\section{Efeito da adubação nitrogenada e potássica na produtividade e na intensidade da mancha branca do milho}

O equilíbrio nutricional de plantas pode influenciar a resistência a doenças. Com o objetivo de avaliar o efeito de doses crescentes de $\mathrm{N}$ e de $\mathrm{K}$ na produtividade e na severidade da mancha branca do milho, foram instalados em campo, dois experimentos, um em Ijaci, MG e o outro em Sete Lagoas, MG. O delineamento experimental foi em blocos casualizados com esquema de análise de variância fatorial $5 \times 5$ e quatro repetições. Os tratamentos consistiram de 5 doses de $\mathrm{N}\left(20 ; 40 ; 80 ; 150 ; 190 \mathrm{Kg} \mathrm{ha}^{-1}\right.$ de $\mathrm{N}$ nos experimentos 1 e 2$)$ e de 5 doses de $\mathrm{K}(15 ; 30 ; 60 ; 120 ; 180 \mathrm{Kg}$ ha ${ }^{1}$ de $\mathrm{K}$ no experimento 1 e 8,75; 17,5; 35; 50; $100 \mathrm{Kg} \mathrm{ha}^{-1}$ de $\mathrm{K}$ no experimento 2). Foi plantado nos dois experimentos o cultivar suscetível 30P70. As parcelas foram constituídas de quatro fileiras de $5 \mathrm{~m}$ de comprimento, sendo a área útil composta por duas linhas centrais com $3 \mathrm{~m}$ cada. As avaliações iniciaram-se aos 43 dias após emergência (DAE) no primeiro e aos $56 \mathrm{DAE}$, no segundo experimento. Não houve interação significativa entre as doses de $\mathrm{N}$ e de $\mathrm{K}$ e o

\footnotetext{
Submitted on 04/23/2014 and approved on 07/08/2015.

${ }^{1}$ This paper is part of the first author's master dissertation.

${ }^{2}$ Universidade Federal de Lavras, Departamento de Fitopatologia, Lavras, Minas Gerais, Brazil.gabrieldornelas@yahoo.com.br

${ }^{3}$ Universidade Federal de Lavras, Departamento de Fitopatologia, Lavras, Minas Gerais, Brazil.eapozza@ dfp.ufla.br; pauleste@dfp.ufla.br

${ }^{4}$ Embrapa Milho e Sorgo, Gurupi, Tocantins, Brazil. rodrigo.veras@embrapa.br

${ }^{5}$ Universidade Federal de Lavras, Departamento de Ciência do Solo, Minas Gerais, Brazil. adelia.pozza@ dcs.ufla.br

${ }^{6}$ Universidade Estadual do Centro Oeste, Departamento de Agronomia, Guarapuava, Paraná, Brazil. leandro.alvarenga.s@ hotmail.com

* Corresponding author: gabrieldornelas@yahoo.com.br
} 
progresso da doença. O efeito foi observado apenas para o N. O K não influenciou a produtividade e a severidade da doença nesses experimentos. Observaram-se maiores áreas abaixo da curva de progresso da severidade da mancha branca e maior produtividade com o aumento das doses de N. Sendo assim, com o aumento das doses de N houve aumento da mancha branca do milho e também da produtividade.

Palavras-chave: Estresse nutricional, Zea mays L., doenças foliares.

\section{INTRODUCTION}

The white spot - Pantoea ananatis (PaccolaMeirelles et al., 2001; Bomfeti et al., 2008), is one of the most important diseases in corn crop. Historically, it only occurred at the end of the cycle of the crop; however, high severity was observed in young plants, during the vegetative phase, resulting in premature wilt of plants in susceptible genotypes (Mendes \& Tebaldi, 2011). The disease occurs in temperature and relative humidity higher than or equal to $14^{\circ} \mathrm{C}$ and $60 \%$, respectively (Rolim et al., 2007) in regions above 700 m.a.s.l. (altitude) (Silva \& Menten, 1997), due to the longer duration of leaf wetness period, provided by dew. In these conditions, damages can cause losses of up to $60 \%$ of corn yield (Rolim et al., 2007).

Among environmental factors that influence the occurrence of the disease, some studies have highlighted the important role of temperature and water (Fernandes et al., 1995; Fantin et al., 2005). However, few studies have described the interaction of mineral nutrition with this disease. The nutritional status of plants is an environmental factor that can be manipulated with relative ease, via fertilization. The supply of nutrients in a balanced way assists in building of several horizontal resistance barriers, including the wax layer (Pozza et al., 2004) and the cell wall, responsible for slowing the penetration and colonization of the pathogen, reducing the epidemic progress rate (Pozza \& Pozza, 2012).

In the literature, there are several reports about how the effect of macro and micro nutrients promote reduction of the intensity of diseases in different crops, such as cercosporiosis (Pozza et al., 2001; 2004; Garcia Júnior et al., 2003) and the stain of Phoma in coffee trees (Lima et al., 2010), anthracnose in strawberries (Tanaka et al., 2002), Phoma in Brassicas (Sochting $\&$ Verret, 2004) and the perforations in plum leaves (Tutida et al., 2007) among others.

When it comes to corns, nutritional imbalances between $\mathrm{N}$ and $\mathrm{K}$ predisposed plants of two cultivars to infection by Colletotrichum graminicola (Ces.) Wils. (SensuArx, 1957). In both cultivars, the amount of damaged leaf area depended on the interaction between the nutrients. The lowest severity levels were observed at the lowest dose of $\mathrm{N}$, combined to the highest dose of $\mathrm{K}$, and nitrogen fertilization influenced the $\mathrm{K}$ content negatively in the upper canopy. Caldwell et al. (2002) also report an increase in the severity of cercosporiosis (Cercospora zeae maydis Tehon \& Daniels) of corn with increased doses of $\mathrm{N}\left(0,60\right.$ and $\left.120 \mathrm{Kg} \mathrm{ha}^{-1}\right)$ and $\mathrm{K}(0$, 25, 50 and $150 \mathrm{Kg} \mathrm{ha}^{-1}$ ) in the soil. However, there is still no information about the influence of $\mathrm{N}$ and $\mathrm{K}$ have upon the maize white spot.

Therefore, this study was performed in order to assess the effect of nitrogen and potassium fertilization on the yield and intensity of the white spot infection of corn.

\section{MATERIALAND METHODS}

The experiments were installed in two field areas. The first one was implemented on 11/25/2011, in an area located on Palmital farm of the Universidade Federal de Lavras (UFLA), in the city of Ijaci, Minas Gerais, located at $21^{\circ} 09^{\prime} 50^{\prime \prime} \mathrm{S}, 44^{\circ} 55^{\prime} 09^{\prime}$ 'W and 837 m.a.s.1. (altitude). The second experiment was implemented on 11/18/2011, in EMBRAPA Milho e Sorgo's experimental area, in the city of Sete Lagoas, Minas Gerais, 19²6'00"S, 44 ${ }^{\circ} 10^{\prime} 59^{\prime \prime} \mathrm{W}$ and 732 m.a.s.l. (altitude). In both experiments, the Pioneer® $30 \mathrm{P} 70$ corn was cultivated, a simple hybrid likely to develop the white spot. The experiments were conducted under natural infection. The soil preparation was done by minimum cultivation with scarification and harrowing on the sowing eve.

The experimental design was installed in randomized blocks, in 5 x 5 factorial design, and four repetitions. The treatments corresponded to five doses of $\mathrm{N}$ and five doses of $\mathrm{K}$ combined with each other, in each area. The $\mathrm{N}$ doses were 20, 40, 80, 150 and $190 \mathrm{Kg} \mathrm{ha}^{-1}$. The doses of $\mathrm{K}$ were calculated individually in each experimental area, according to the results of soil analysis (Table 1) and 
following the recommendations for the crop in Minas Gerais (Ribeiro et al., 1999). The doses of K were 15, $30,60,120$ and $180 \mathrm{Kg} \mathrm{ha}^{-1}$ of $\mathrm{K}_{2} \mathrm{O}$ for experiment 1 and $8.75,17.5,35,50$ and $100 \mathrm{Kg} \mathrm{ha}^{-1}$ of $\mathrm{K}_{2} \mathrm{O}$ for experiment 2. The parts consisted of four rows of $5 \mathrm{~m}$ long and the useful area by two central rows of $3 \mathrm{~m}$ each. The sources of $\mathrm{N}$ and $\mathrm{K}$ were urea and potassium chloride, respectively. Twenty-five percent and $50 \%$ of doses of $\mathrm{N}$ and $\mathrm{K}$ respectively were applied at sowing, and the rest was divided in two side dressings, one 35 days after sowing and the other 15 days after the first one.

In addition to $\mathrm{N}$ and $\mathrm{K}, 120$ and $70 \mathrm{Kg} \mathrm{ha}^{-1}$ of $\mathrm{P}_{2} \mathrm{O}_{5}$ were applied in experiments 1 and 2, respectively and, 2 $\mathrm{Kg} \mathrm{ha}^{-1}$ of $\mathrm{Zn}$ in the form of zinc sulphate and $30 \mathrm{Kg} \mathrm{ha}^{-1}$ of calcium sulfate (14\% of $\mathrm{S}$ ) in the form of phosphogypsum, according to the results of soil analysis and recommendations of Ribeiro et al., (1999), at sowing date. Two micronutrient sprays of $2.0 \mathrm{~L} \mathrm{~h}^{-1}$ containing $5 \% \mathrm{Zn}, 3 \% \mathrm{Mn}, 0.50 \%$ of $\mathrm{B}, 0.60 \% \mathrm{Cu}, 0.06 \%$ Mo and 4\% S in $200 \mathrm{~L} \mathrm{ha}^{-1}$ of water were also applied, in stages V3 and V6, (Ritchie et al., 2003), that is, 30 and 45 days after planting.

Planting fertilization and zinc sulfate and phosphogypsum were applied in the furrow. Sowing was performed manually, at a spacing of $0.70 \times 0.20 \mathrm{~m}$. For weed control, applications of glyphosate $\left(2.0 \mathrm{~L} \mathrm{ha}^{-1}\right)$ were used at pre-emergence and nicosulfuron $\left(1.5 \mathrm{~L} \mathrm{ha}^{-1}\right)$ mixed with atrazine $\left(5.0 \mathrm{~L} \mathrm{ha}^{-1}\right)$ as post-emergence herbicides.

The evaluation of the disease severity was initiated at 43 and 56 days after emergence (DAE) in experiment 1 and 2, respectively, with the appearance of the first symptoms. From then on, evaluations were carried out every 10 days, totaling six and seven evaluations, in areas 1 and 2, respectively. These severity evaluations were performed with the help of diagrammatic scale (Agroceres, 1996). The data was used to calculate the area under the curve of progress of disease severity (AUCPS), according to Shanner \& Finney (1977).

After the manual harvest the grains were threshed, weighted and the humidity content was determined. Grain yield data were refined to $13 \%$ of humidity content and expressed in $\mathrm{t} \mathrm{ha}^{-1}$. Climatic variables were monitored by minimum, maximum and average temperatures, average relative humidity and precipitation, in both places with Campbell Scientific ${ }^{\circledR}$ weather stations implemented near the experiments.

Data of the AUCPS and of grain yield, from each experiment, were submitted to analysis of variance. Then, the significant variables in the F test were submitted to the adjustment of linear regression models. Pearson's correlation analysis were performed between yield and the AUCPS of both experiments. Analysis were conducted in the SAS ${ }^{\circledR}$ program (SAS Institute Inc., 1996).

\section{RESULTS AND DISCUSSION}

The average of the maximum, average and minimum daily temperatures, during the conduction period of the experiments were 28,22 and $18{ }^{\circ} \mathrm{C}$. Average relative humidity was of $76 \%$ and precipitation of $1078 \mathrm{~mm}$ in experiment 1 (Figure $1 \mathrm{~A}$ ). In experiment 2 , the maximum, average and minimum daily temperatures were 29,22 and $18^{\circ} \mathrm{C}$, and the average relative humidity was $74 \%$ and the precipitation was $1225 \mathrm{~mm}$ (Figure 1B). According to Oliveira et al. (2004) and Reis et al. (2004) the weather conditions favorable to the occurrence of white spot are relative humidity above $60 \%$, high precipitation and moderate temperatures between 20 to $25^{\circ} \mathrm{C}$.

\section{Area under the curve of progress of disease severity (AUCPS)}

In both experiments there was no significant interaction $(\mathrm{P} \geq 0,05)$ between $\mathrm{N}$ and $\mathrm{K}$ to the AUCPS of the white spot (Table 2). However, the increasing doses of $\mathrm{N}$ influenced the AUCPS.

With the increase of $\mathrm{N}$ doses, a linear rise of AUCPS was observed. There was an increase of 23.8 (Figure 2A) and $51.7 \%$ (Figure 2B) in disease severity from 20 to $190 \mathrm{Kg} \mathrm{ha}^{-1}$ of $\mathrm{N}$ in experiments 1 and 2, respectively. The contribution of nitrogen fertilizer on plants' resistance to diseases varies, among other factors, depending on the pathogen, genotype, dose and source of the nutrient used and on the interaction between nutrients (Pozza \& Pozza, 2012). Appropriate doses of

Table 1: Results of chemical analyses of the soils in Sete Lagoas - MG (Soil 1) and Ijaci-MG (Soil 2) prior to the establishment of the experiment

\begin{tabular}{|c|c|c|c|c|c|c|c|c|c|c|c|}
\hline \multirow{2}{*}{ Soil } & \multirow{2}{*}{$\mathbf{p H}$} & P-rem & $\mathbf{P}$ & $\mathbf{K}$ & $\mathrm{Ca}$ & Mg & Al & $\mathrm{H}+\mathrm{Al}$ & SB & $\mathbf{T}$ & $\mathbf{V}$ \\
\hline & & $\overline{\text { mg L L }^{-1}}$ & \multicolumn{2}{|c|}{$\mathrm{mg} \mathrm{dm}^{-3}$} & \multicolumn{4}{|c|}{$\mathrm{cmol}_{\mathrm{c}} \mathrm{dm}^{-3}$} & \multicolumn{2}{|c|}{$\mathrm{cmol}_{\mathrm{c}} \mathrm{dm}^{-3 \%}$} & \\
\hline Soi1 $^{(1)}$ & 5.8 & 15.6 & 3.4 & 47 & 2.0 & 0.3 & 0.1 & 3.2 & 2.4 & 5.7 & 42.8 \\
\hline Soil2(2) & 6.8 & 20.1 & 22.0 & 107 & 4.7 & 0.6 & 0.0 & 2.1 & 5.6 & 7.7 & 72.9 \\
\hline
\end{tabular}

${ }^{(1)}$ Soil Analysis Laboratory of the Department of Soil Science (UFLA).

${ }^{(2)}$ Soil Analysis Laboratory of the Department of Soil (UFV). 


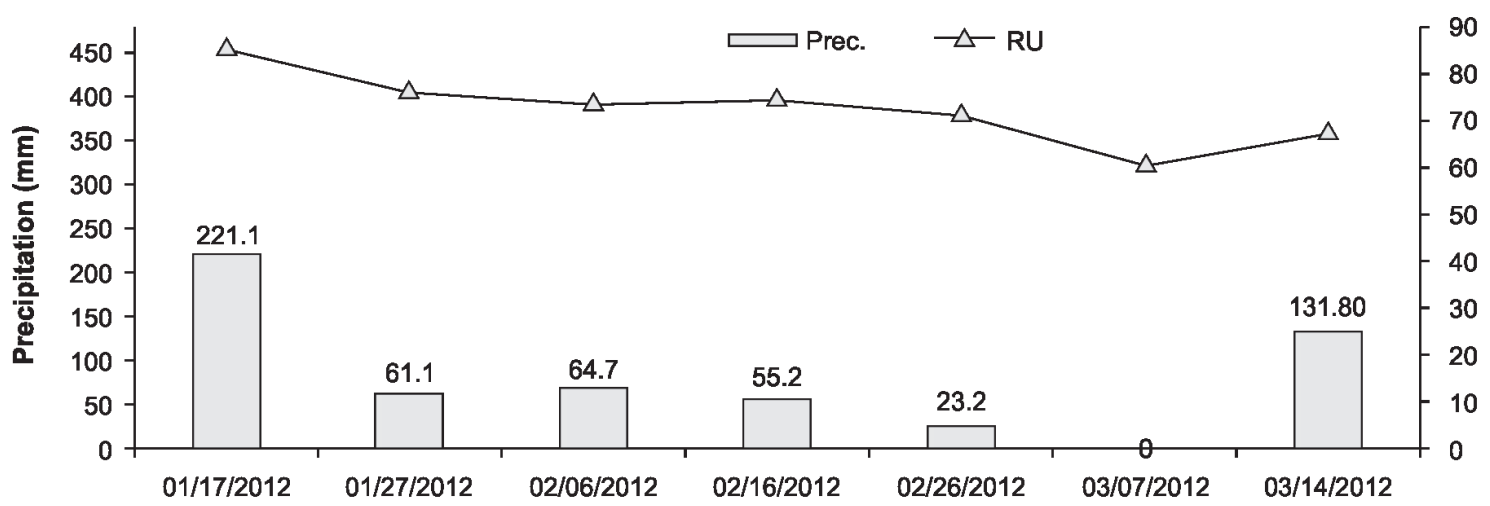

B
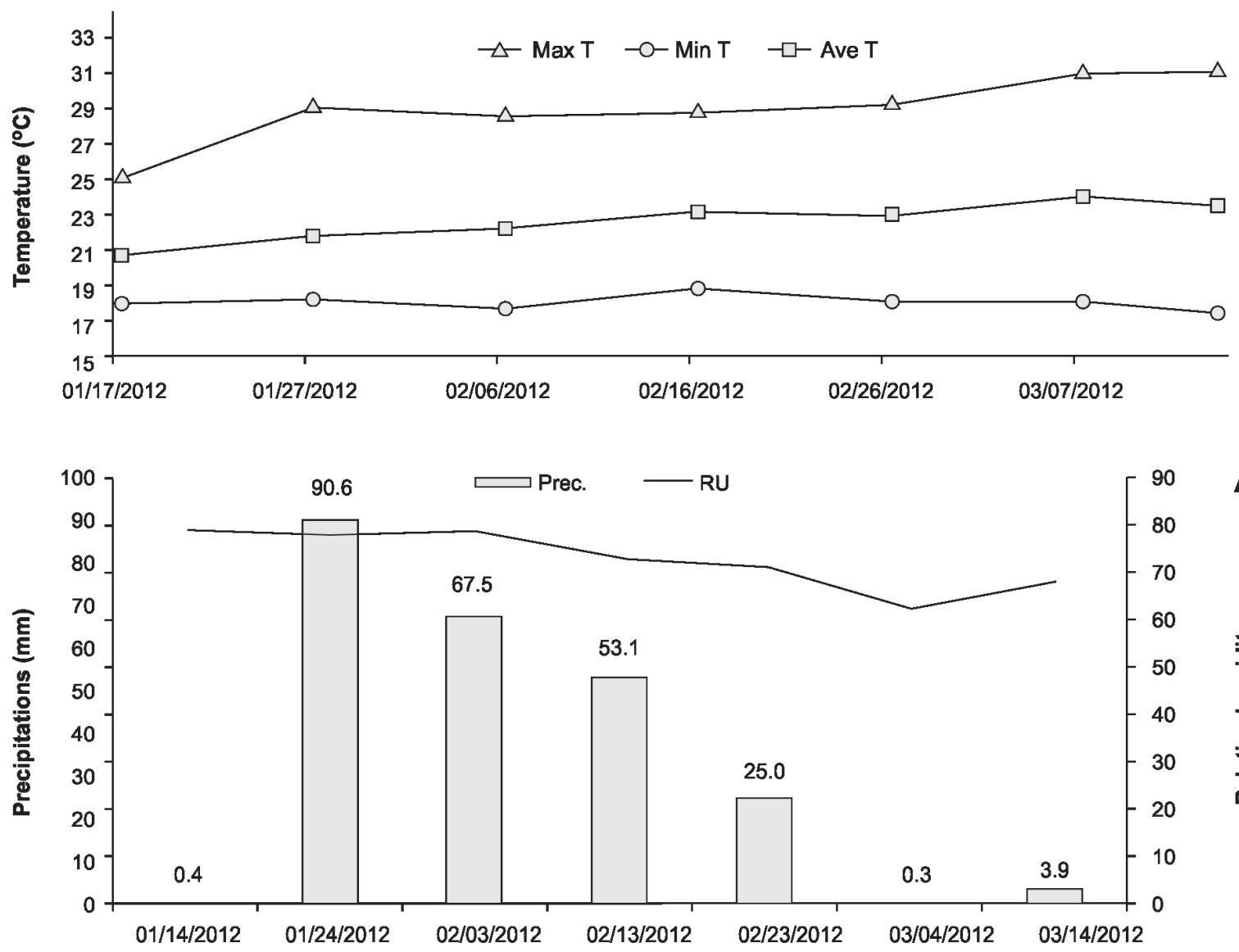

A

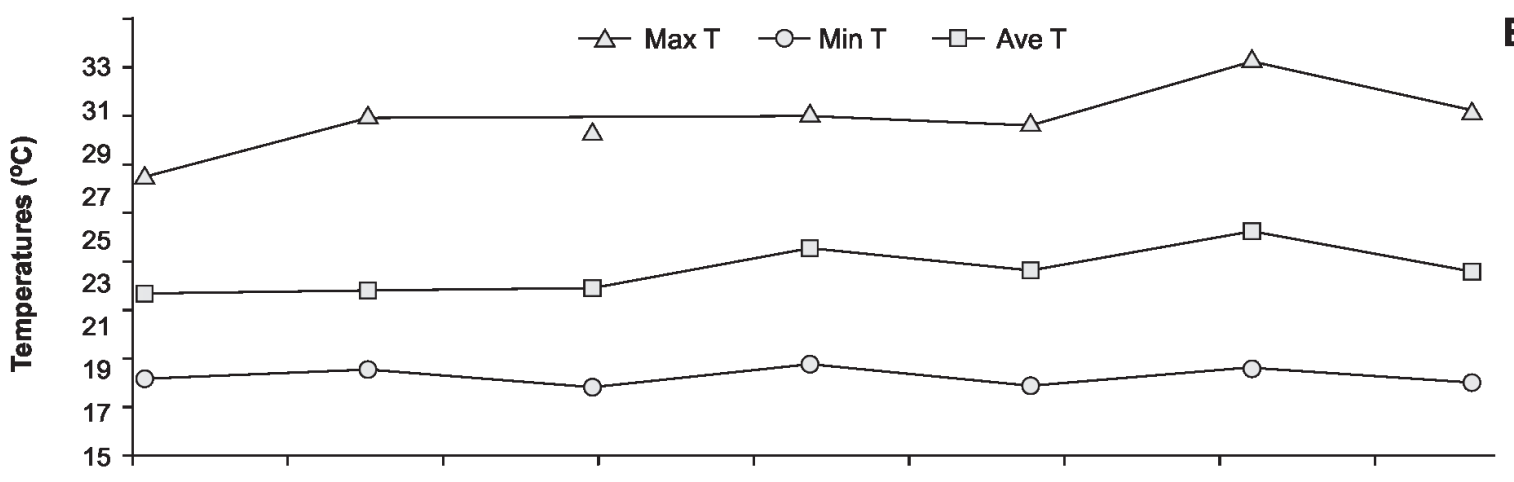

B

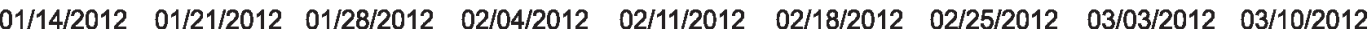

Figure 1: A) Total precipitation, relative humidity, maximum temperature, average temperature and minimum temperature in Ijaci (experiment 1) of 01/17/2012 to 03/14/2012 and in B) Sete Lagoas (experiment 2). Data obtained in the Bioclimatology sectors of UFLA, and EMBRAPA 
$\mathrm{N}$ contributes to the synthesis of lignin, phytoalexins and tannins, but in excess, $\mathrm{N}$ reduces the production of these compounds, due to the demand of carbon in photosynthesis via cycle of Krebs. Thus, the synthesis of the secondary metabolites via shikimic acid is compromised and the turgor cell also raises, providing greater amounts of water and also the production of carbohydrates, such as glucose (Huber \& Thompson, 2007; Taiz \& Zieger, 2013), essential to the infection process of the pathogen. In addition, horizontal resistance barriers as the layer of wax and also the cell wall may be compromised due to the rapid cell growth, making them thinner and less resistant to fungal penetration (Pozza \& Pozza, 2012).

Similarly, Fidelis et al. (2003), relate the increased severity of the white spot of corn in early stages of growth with high doses of $\mathrm{N}$ compared to lower doses. The reaction of 23 cultivars of corn, submitted to low $\mathrm{N}$ (32 $\mathrm{Kg} \mathrm{ha}^{-1}$ of $\mathrm{N}$ at sowing) and to high $\mathrm{N}$ supply (32 $\mathrm{Kg} \mathrm{ha}^{-1}$ at sowing $+90 \mathrm{Kg} \mathrm{ha}^{-1}$ of $\mathrm{N}$ on side dressing), was 6 and $30 \%$ of the severity of white spot, respectively, at 30 days after flowering.

Table 2: Summary of the analysis of variance for severity of white spot and yield of corn, according to the doses of $\mathrm{N}$ and $\mathrm{K}$ in experiment 1 (Ijaci) and in experiment 2 (Sete Lagoas)

\begin{tabular}{|c|c|c|c|c|c|c|c|}
\hline \multicolumn{8}{|l|}{ Experiment 1} \\
\hline \multirow{2}{*}{ FV } & \multirow{2}{*}{ GL } & \multicolumn{3}{|c|}{ Severity } & \multicolumn{3}{|c|}{ Productivity } \\
\hline & & $\mathbf{Q} \mathbf{M}_{\mathrm{Sev}}$ & Fc & $\operatorname{Pr}>$ Fc & $\mathbf{Q M}_{\text {Prod }}$ & Fc & $\operatorname{Pr}>\mathrm{Fc}$ \\
\hline Doses of $\mathrm{N}$ & 4 & 1614496.9 & 17.60 & $0.00 * *$ & 58.53 & 59.69 & $0.00 * *$ \\
\hline Doses of K & 4 & 82454.8 & 0.90 & $0.46^{\mathrm{ns}}$ & 1.15 & 1.17 & $0.33^{\mathrm{ns}}$ \\
\hline Doses N x K & 16 & 68376.7 & 0.75 & $0.73^{\mathrm{ns}}$ & 2.74 & 2.79 & $0.00^{\mathrm{ns}}$ \\
\hline Block & 3 & 129095.6 & 1.41 & $0.24^{\mathrm{ns}}$ & 0.14 & 0.14 & $0.93^{\mathrm{ns}}$ \\
\hline Error & 72 & 91717.8 & - & - & 0.98 & - & - \\
\hline
\end{tabular}

\begin{tabular}{|c|c|c|c|c|c|c|c|}
\hline $\mathrm{CV}(\%)$ & & & & 9.97 & & & 13.85 \\
\hline \multicolumn{8}{|c|}{ Experiment 2} \\
\hline \multirow{2}{*}{ FV } & \multirow{2}{*}{ GL } & Severity & \multicolumn{2}{|l|}{ Productivity } & & & \\
\hline & & $\mathbf{Q} \mathbf{M}_{\text {Sev }}$ & Fc & $\mathrm{Pr}>\mathrm{Fc}$ & $\mathbf{Q M}_{\text {Prod }}$ & Fc & $\operatorname{Pr}>\mathrm{Fc}$ \\
\hline Doses of $\mathrm{N}$ & 4 & 5524974.8 & 52.85 & $0.00 * *$ & 64.55 & 22.03 & $0.00 * *$ \\
\hline Doses of K & 4 & 180333.8 & 1.73 & $0.15^{\mathrm{ns}}$ & 2.99 & 1.02 & $0.40^{\mathrm{ns}}$ \\
\hline Dose $\mathrm{N}$ x K & 16 & 86976.5 & 0.83 & $0.64^{\mathrm{ns}}$ & 1.08 & 0.37 & $0.98^{\mathrm{ns}}$ \\
\hline Block & 3 & 333440.7 & 3.19 & $0.03^{*}$ & 3.78 & 1.29 & $0.28^{\mathrm{ns}}$ \\
\hline Error & 72 & 104537.1 & - & - & 2.93 & - & - \\
\hline$\overline{\mathrm{CV}}(\%)$ & & & & 11.04 & & & 27.45 \\
\hline
\end{tabular}

${ }^{n s}$ non-significant

** and $*$ significant, probability of 1 e $5 \%$, by $\mathrm{F}$ test, respectively.
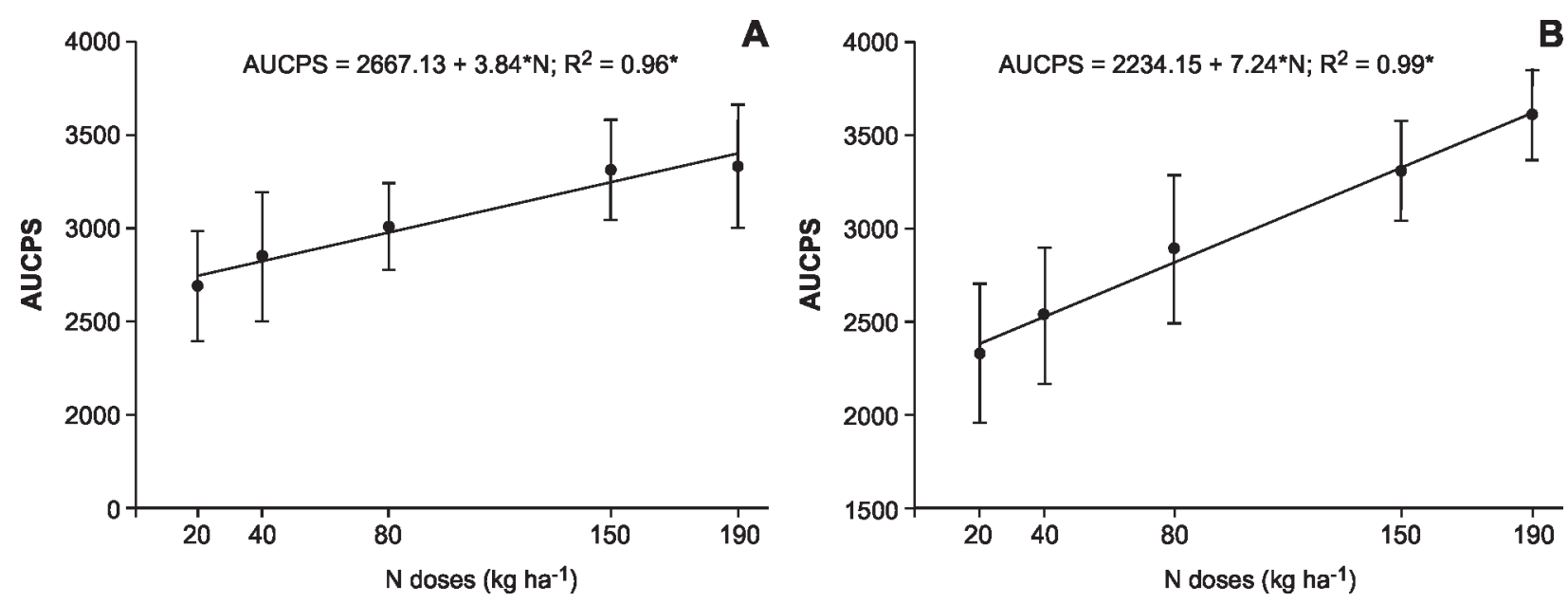

Figure 2: Area under the curve of progress of disease severity (AUCPS) of the white spot in the corn crop depending on the $\mathrm{N}$ doses, (A) experiment 1 (Ijaci) and (B) experiment 2 (Sete Lagoas). 
However, other authors, studying the isolated effect of $\mathrm{N}$ on the severity of the white spot on the corn, found no significant effects of nitrogen fertilization and the intensity of the disease. Pegoraro et al. (2001) relate no substantial differences among six corn hybrids to the reaction of the white spot with two doses of nitrogen fertilization (42.5 and $85 \mathrm{Kg} \mathrm{ha}^{-1}$ of $\mathrm{N}$ ). According to the authors, these $\mathrm{N}$ doses were high enough to ensure the nutrition of plants not favoring high intensities of the white spot on the corn. Meanwhile, these doses were lower than the last two used in experiments of this study and, also lower than the highest dose used in the experiment of Fidelis et al. (2003). The results obtained by Pegoraro et al. (2001) also agree with Duarte et al. (1999) and Souza \& Duarte (2002) in experiments with lower doses of $\mathrm{N}$ (8 and $32 \mathrm{Kg} \mathrm{ha}^{-1}$ ), in which changes in the susceptibility of cultivars to the white spot were not observed. But these authors also did not study how much the dose can increase without causing increment in the intensity of the disease, as studied in this work.

In other pathosystems, $\mathrm{N}$ can both reduce and increase diseases. The tropical rust (Physopella zeae (Mains) Cummins \& Ramachar) of the corn (Tomazela et al., 2006), for example, increased with the addition of $200 \mathrm{Kg} \mathrm{ha}^{-1}$ of $\mathrm{N}$, also followed by increased yield. This study reports the importance of nitrogen fertilization favoring foliar diseases of the corn, although it did not study the interaction with other nutrients and did not quantify its increment in relation to higher doses over time.

Still in relation to the corn, Carvalho et al. (2013), studying the interaction of doses of $\mathrm{N}(75,150,300$, 600 and $\left.1200 \mathrm{mg} \mathrm{dm}^{-3}\right)$ and $\mathrm{K}(63,125,250,500$ and $1000 \mathrm{mg} \mathrm{dm}^{-3}$ ) in pots, and two cultivars, one moderately resistant and the other highly susceptible, report an interaction between $\mathrm{N}$ and $\mathrm{K}$. According to these authors, for both cultivars, the largest leaf area injured (LAI) was obtained in the treatment with the lowest doses of $\mathrm{N}$ and $\mathrm{K}\left(75 \mathrm{mg} \mathrm{dm}^{-3} \mathrm{de} \mathrm{N}\right.$ and $63 \mathrm{mg} \mathrm{dm}^{-3}$ of $\mathrm{K}$, respectively. The increasing of the doses of $\mathrm{N}^{-\mathrm{NH}_{4}}{ }^{+}$reduced the $\mathrm{K}$ content in the upper canopy, for both cultivars.

In this paper, the amount of $\mathrm{K}$ that already present in both soils (Table 1), may have contributed to supply the plants without needing to provide the doses via fertilization. This can be the cause of the lack of interaction between the two nutrients on the severity of the disease. For future researches, it is necessary to find soils with low levels of $\mathrm{K}$.

\section{Grain Yield}

For grain yield, the interaction between the doses of $\mathrm{N}$ and $\mathrm{K}$ was not significant $(\mathrm{P} \geq 0,05)$ for both experiments, but the doses of $\mathrm{N}(\mathrm{P}<0,01)$ influenced this variable (Table 2).

In experiment 1 , the quadratic effect of the $\mathrm{N}$ dose on grain yield was observed. The increment of nitrogen fertilization to dose $170.5 \mathrm{Kg} \mathrm{ha}^{-1}$ (Figure 3A) increased yield. The response of the $\mathrm{N}$ doses compared to the lowest dose $\left(20 \mathrm{Kg} \mathrm{ha}^{-1}\right)$ was $18.8,48.2,73.7$, $73.4 \%$ in the doses $40,80,150$ and $190 \mathrm{Kg} \mathrm{ha}^{-1}$, respectively. For each $\mathrm{Kg}$ of $\mathrm{N}$ applied to the soil, an increase of 47.0, 40.2, 28.4, 21.6 $\mathrm{Kg} \mathrm{ha}^{-1}$ of grain was obtained, in the doses 40, 80, 150 and $190 \mathrm{Kg} \mathrm{ha}^{-1}$, respectively, compared to the lowest dose. In the treatment with the highest dose of $\mathrm{N}\left(190 \mathrm{Kg} \mathrm{ha}^{-1}\right)$, yield was $3,677 \mathrm{Kg} \mathrm{ha}^{-1}$ greater than the lower dose (40 $\mathrm{Kg} \mathrm{ha}^{-1}$ ).

In experiment 2 , a rising linear effect to the $\mathrm{N}$ (Figure $3 \mathrm{~B})$ was observed. The increase in grain yield compared to the lowest dose $\left(20 \mathrm{Kg} \mathrm{ha}^{-1}\right)$ was $0.56 \%$ per $\mathrm{Kg}$ of $\mathrm{N}$ applied. That is, there was an increase of 11.3, $34.0,73.7,96.4 \%$ in the doses 40, 80, 150 and $190 \mathrm{Kg}$ $\mathrm{ha}^{-1}$, respectively. For each $\mathrm{Kg}$ of $\mathrm{N}$ applied, an increase of $24.6 \mathrm{Kg} \mathrm{ha}^{-1}$ of grain was obtained. In the treatment with the highest dose of $\mathrm{N}\left(190 \mathrm{Kg} \mathrm{ha}^{-1}\right)$ the yield was $4,200 \mathrm{Kg} \mathrm{ha}^{-1}$ more grains than the lowest dose $(20 \mathrm{Kg}$ $\left.\mathrm{ha}^{-1}\right)$.

The use of high doses of $\mathrm{N}$ has contributed to the increment in the yield of grain in the majority of the researches done, being fundamental in the composition of the yield of the corn crop. An example of this was the increased yield of corn with $147 \mathrm{Kg} \mathrm{ha}^{-1}$ of $\mathrm{N}$, in direct planting, without irrigation, in the Brazilian "cerrado", obtained by Fernandes et al. (1999). Also Silva et al. (2005), in the region of Ilha Solteira, São Paulo, obtained the maximum yield of rain-fed corn, achieved with the dose of $166 \mathrm{Kg} \mathrm{ha}^{-1}$ of $\mathrm{N}$. In another experiment in the same region, the maximum efficiency of $\mathrm{N}$ was achieved with doses between 144 and $174 \mathrm{Kg} \mathrm{ha}^{-1}$ and with quadratic response to doses of $\mathrm{N}$ (Silva et al., 2006).

According to Sousa \& Lobato (2004,) corn plants require around $20 \mathrm{Kg} \mathrm{ha}^{-1}$ of $\mathrm{N}$ per ton of grains produced. Thus, in the present experiments, income below the expected to the largest dose was obtained, that is, in experiment $1,21.90 \mathrm{Kg}$ per ton of corn was spent, which is equivalent to a loss of $9 \%$, and in experiment $2,22.20$ $\mathrm{Kg}$ per ton of corn were spent, equivalent to a $10 \%$ of loss. Nevertheless, this loss can be related to the severity of the white spot, which contributed to the reduction of yield.

Once $\mathrm{K}$ did not contribute to an increase in yield, Pavinato et al. (2008) conducted an experiment with six doses of $\mathrm{N}\left(0,80,120,160,200\right.$ and $\left.240 \mathrm{Kg} \mathrm{ha}^{-1}\right)$ in the form of urea and four doses of $\mathrm{K}_{2} \mathrm{O}(0,40,80$ and 

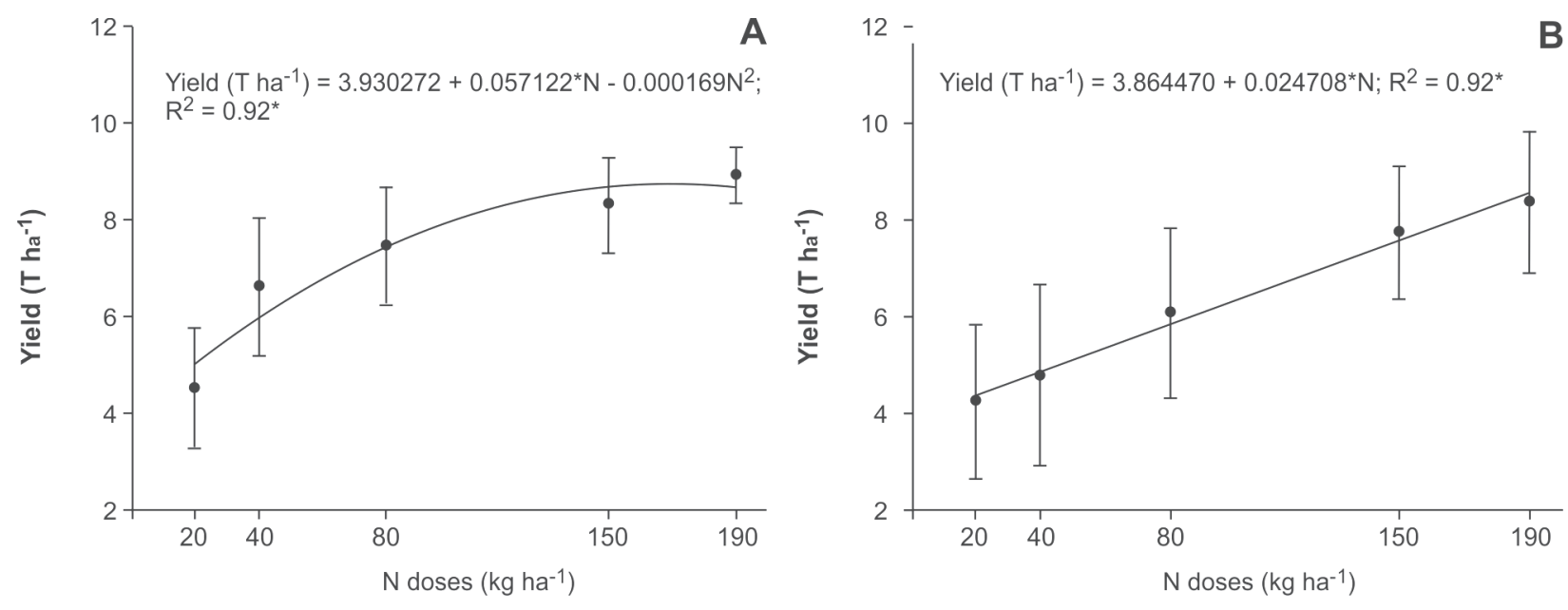

Figure 3: Yield of corn kernels (t ha-1) in relation to increasing doses of $\mathrm{N}$ (A) in experiment 1 (Ijaci) and (B) in experiment 2 (Sete Lagoas).

$120 \mathrm{Kg} \mathrm{ha}^{-1}$ ), allocated in bi-factorial design, and also did not observe an increase in yield of corn when higher doses of $\mathrm{K}$ were applied. They relate that yield was not affected by the application of $\mathrm{K}$ and justified this by the high levels of $\mathrm{K}$ available in the soil. However, there was an increment with the doses of $\mathrm{N}$ and there was no significant interaction observed between $\mathrm{N}$ and $\mathrm{K}$ fertilizers. These results are similar to those found in experiments 1 and 2 described above, in which doses of $\mathrm{K}$ did not affect the yield of grain, which is only dependent of increased doses of $\mathrm{N}$. The lack of interaction between the two nutrients (Table 2) can also be justified by "medium and good" rates of the levels of $\mathrm{K}$ in the soil (47 and $107 \mathrm{mg} \mathrm{dm}^{-3}$ ), in experiments 1 and 2 respectively (Table 1 ) according to the tables of interpretation of results of soil analysis presented by Ribeiro et al., (1999).

Positive and significant values were observed for correlations between the severity of the disease (AUCPS) and grain yield ( $\left.\mathrm{tha}^{-1}\right)$, that is, with both $\mathrm{N}$ or $\mathrm{K}$ increasing (Table 3).

In the biggest AUCPS, grain yield was higher, this could be explained by the fact that $\mathrm{N}$ is the main nutrient for increasing yield and it is required in greater amounts by the crop, but it also encourages the severity of the pathogen. In this pathossystem, other studies showed different correlations, perhaps due to the low doses of $\mathrm{N}$

Table 3: Pearson's correlation coefficients between grain yield and the area below the disease progress curve, considering both experiments ( 1 - Ijaci and 2 - Sete Lagoas)

\begin{tabular}{lcc}
\hline \multirow{2}{*}{ Treatments } & \multicolumn{2}{c}{ AUCPS } \\
\cline { 2 - 3 } & Experiment 1 & Experiment 2 \\
\hline Yield of grains & $0.42^{* *}$ & $0.90^{* *}$ \\
\hline$*$ Significant, probability of $1 \%\left(\mathrm{H}_{0}: \mathrm{r}=0\right)$
\end{tabular}

used in these researches. For example, Souza \& Duarte (2002) with doses of $\mathrm{N}\left(8 \mathrm{Kg} \mathrm{ha}^{-1}\right.$ and $\left.32 \mathrm{Kg} \mathrm{ha}^{-1}\right)$ found no correlation between white spot and corn yield. On the other hand, Brito et al. (2012), in an experiment with chemical control of white spot, with the same fertilization (36 Kg ha-1 at sowing $+90 \mathrm{Kg} \mathrm{ha}^{-1}$ of $\mathrm{N}$ as side dressing), found a negative correlation between the severity of white spot and yield, $-0.41,-0.37,-0.46$ in the cities of Lavras, Passos and Patos de Minas, respectively.

In another pathossystem, however, Vaz-de-Melo et al. (2010) observed the reaction of corn hybrids to Curvularia ssp on two levels of fertilization with $\mathrm{N}$ (high - $80 \mathrm{Kg} \mathrm{ha}^{-1}$ and low - $40 \mathrm{Kg} \mathrm{ha}^{-1}$ ) and found a significant correlation between the severity of the Curvularia spot with yield. Nevertheless, the correlation between Curvalaria severity and yield was weak and negative (0,178 ) under high $\mathrm{N}$ conditions but negative and stronger under low N supply. Such results points out the effects of the disease severity on yield under limiting $\mathrm{N}$ conditions.

Therefore, the use of balanced mineral nutrition can help establish integrated management program allowing greater efficiency to control the white spot on the corn, in addition to strategy based on evasion and protection, in order to reduce the damage of this disease in plantations. Although $\mathrm{N}$ has raised the severity of the disease, yield also increased in response to the doses applied in the soil, requiring recommendations of additional management practices for better efficiency.

\section{CONCLUSIONS}

Under the conditions that the experiments were conducted, the increase of dose of nitrogen favored the yield and the severity of the white spot on the corn. 


\section{REFERENCES}

Agroceres (1996) Guia Agroceres de Sanidade. $2^{a}$ ed. São Paulo, Sementes Agroceres. 72p.

Bomfeti CA, Souza-Paccola EA, Júnior Massola NS, Marriel IE, Meirelles WF, Casela CR \& Paccola-Meirelles LD (2008) Localization of $P$. ananatis inside lesions of maize white spot disease using transmission electron microscopy and molecular techniques. Tropical Plant Pathology, 33:63-66

Brito AH, Pereira JLAR, Von Pinho RG \& Balestre M (2012) Controle químico de doenças foliares e grãos ardidos em milho (Zea mays L.). Revista Brasileira de Milho e Sorgo, 11:49-69.

Caldwell PM, Ward JMJ, Miles N \& Laing MD (2002) Assessment of the effects of fertilizer applications on gray leaf spot and yeld in maize. Plant Disease, 86:859-866.

Carvalho DO, Pozza EA, Casela CR, Costa RV, Pozza AAA \& Carvalho CO (2013) Adubação nitrogenada e potássica na severidade da antracnose em dois cultivares de milho. Revista Ceres, 60:380-387.

CONAB - Companhia Nacional de Abastecimento (2014) $5^{\circ}$ Levantamento - Safra Agrícola de Grãos 2013/2014. Disponível em: <http:// www.conab.br> Acessado em: 21 de fevereiro de 2014.

Duarte JM, Souza JC \& Corte JR (1999) Reação de cultivares de milho a Phaeospaheria maydis. In: Reunião Latino Americana Del Maiz, Sete Lagoas. Memoriais, Embrapa/CNPMS. p. 405-412.

Fantin GM, Duarte AP, Castro JL, Dudienas C, Pereira JOF, Junior AP, Geller C, Bragato EL, Kirnew PA \& Cruz FA (2005) Severidade em cultivares de milho safrinha na região paulista do Vale do Paranapanema em 2004 e 2005. In: Seminário Nacional de Milho Safrinha. Campinas. Anais, Instituto Agronômico. p. 309-318.

Fernandes FT, Lima P, Sans LMA \& Pinto NFJA (1995) Influência de fatores climáticos na ocorrência de Phyllosticta em milho. Fitopatologia Brasileira, 20:309-318.

Fernandes LA, Vasconcellos CA, Furtini Neto AE, Roscoe R \& Guedes GAA (1999) Preparo do solo e adubação nitrogenada na produção de grãos e matéria seca e acúmulo de nutrientes pelo milho. Pesquisa Agropecuária Brasileira, 34:1691-1698.

Fidelis RR, Miranda GV, Souza LV, Coimbra RR, Melo AV \& Galvão JCC (2003) Reação de cultivares de milho à mancha de Phaeosphaeria em estresse de nitrogênio. Bioscience Journal, 19:27-34.

Garcia Júnior D, Pozza EA, Pozza AAA, Souza PE, Carvalho JG \& Balieiro AC (2003) Incidência e severidade da cercosporiose do cafeeiro em função do suprimento de potássio e cálcio em solução nutritiva. Fitopatologia Brasileira, 28:286-291.

Huber DM \& Thompson IA (2007) Nitrogen and plant disease. In: Datnoff LE, Elmer WH \& Huber DM (Eds.) Mineral nutrition and plant disease. Saint Paul, APS Press. p.31-44.

Lima LM, Pozza EA, Torres HN, Pozza AAA, Salgado M \& Pfenning LH (2010) Relação nitrogênio/potássio com a mancha de Phoma e nutrição de mudas de cafeeiro em solução nutritiva. Tropical Plant Pathology, 35:223-228.

Mendes LS \& Tebaldi ND (2011) Pantoea ananatis: importância, isolamento, cultivo em meio de cultura, inoculação, sobrevivência, disseminação, penetração, colonização e controle para cultura do milho (Zea mays L.). Revisão Anual de Patologia de Plantas, 19:386-399.

Oliveira E, Fernandes FT, Casela CR, Pinto NFJA \& Ferreira AS (2004) Diagnose e controle de doenças na cultura do milho. In: Galvão JCC \& Miranda GV (Eds.) Tecnologias de produção do milho. Viçosa, UFV.p. 227-267.

Paccola-Meirelles LD, Ferreira AS, Meirelles WF, Marriel IE \& Casela CR (2001) Detection of bacterium associated with a leaf spot disease of maize in Brazil. Journal of Phytopathology, 149:275-279.
Pavinato PS, Ceretta CA, Girotto E \& Moreira ICL (2008) Nitrogênio e potássio em milho irrigado: análise técnica e econômica da fertilização. Ciência Rural, 38:358-364.

Pegoraro DG, Vacaro E, Nuss CN, Soglio FK \& Barbosa Neto JF (2001) Efeito de época de semeadura e adubação na mancha foliar de Phaeosphaeria em milho. Pesquisa Agropecuária Brasileira, 36:10371042 .

Pozza AAA, Alves E, Pozza EA, Carvalho JG, Montanari M, Guimarães PTG \& Botelho DMS (2004) Efeito do silício no controle da cercosporiose em três variedades de cafeeiro. Fitopatologia Brasileira, 29:185-188.

Pozza AAA, Martinez HEP, Caixeta SL, Cardoso AA, Zambolim L \& Pozza EA (2001) Influência da nutrição mineral na intensidade da mancha olho pardo em mudas de cafeeiro. Pesquisa Agropecuária Brasileira, 36:53-60.

Pozza EA \& Pozza AAA (2012) A Nutrição Mineral no Manejo de Doenças de Plantas. In: Grupo de Estudos Avançados em Fitopatologia (Ed.). Nutrição no manejo de doenças de plantas. Viçosa, GEAFIP. p.177-212.

Reis EM, Casa RT \& Bresolin ACR (2004) Manual de diagnose e controle de doenças do milho. $2^{a}$ ed. Lages, Graphel. 141p.

Ribeiro AC, Guimarães PTG \& Alvarez VVH (1999) Recomendações para uso de corretivos e fertilizantes em Minas Gerais - $5^{\text {a }}$ Aproximação. Viçosa, Universidade Federal de Viçosa. 359p.

Ritchie SW, Hanway JJ \& Benson GO (2003) Como a planta de milho se desenvolve. Piracicaba, Potafos. 20p. (Informações Agronômicas, 103).

Rolim GS, Pedro Júnior MJ, Fantin GM, Brunini O, Duarte AP \& Dudienas C (2007) Modelo agrometeorológico regional para a estimativa da severidade da mancha de Phaeosphaeria em milho safrinha no estado de São Paulo, Brasil. Bragantia, 66:721-728.

SAS Institute Inc. (2002) Statistical Analysis System user's guide. Version 9.0. Cary, Statistical Analysis System Institute. 513p.

Shanner G \& Finney RE (1977) The effect of nitrogen fertilization on the expression of slow-mildewing resistance in Knox wheat. Phythopatology, 67:1051-1056.

Silva EC, Buzetti S, Guimarães GL, Lazarini E \& Sá ME (2005) Doses e épocas de aplicação de nitrogênio na cultura do milho em plantio direto sobre Latossolo Vermelho. Revista Brasileira de Ciência do Solo, 29:353-362.

Silva EC, Muraoka T, Buzetti S \& Trivelin PCO (2006) Manejo de nitrogênio no milho em Latossolo Vermelho sob plantio direto com diferentes plantas de cobertura. Pesquisa Agropecuária Brasileira, 41:477-486.

Silva HP \& Menten JOM (1997) Manejo integrado de doenças na cultura do milho. In: Fancelli \& Dourado Neto (Eds.) Simpósio sobre a cultura do milho. Piracicaba, ESALQ/FEALQ. p.40-56.

Sochting HP \& Verret JA (2004) Effects of cultivation systems: soil management, nitrogen fertilization on the epidemics of fungal diseases in oil seed rape (Brassica napus L. var. napus). Journal of Plant Diseases and Protection, 111:01-29.

Sousa DMG \& Lobato E (2004) Calagem e adubação para culturas anuais e semiperenes. In: Sousa DMG \& Lobato E (Eds.) Cerrado: correção do solo e adubação. Planaltina, Embrapa Cerrados. p. 283315.

Souza JC \& Duarte JM (2002) Reação de cultivares de milho a Phaeosphaeria maydis. Ciência e Agrotecnologia, 26:325-331.

Taiz L \& Zeiger E (2013) Fisiologia Vegetal. $5^{\text {a }}$ ed. Porto Alegre, Artmed. $918 \mathrm{p}$

Tanaka MAS, Passos FA, Feitosa CT \& Tanaka RT (2002) Efeito da adubação mineral e orgânica do morangueiro sobre a antracnose do rizoma, causada por Colletotrichum fragariae. Summa Phytopathologica, 28:236-241. 
Tomazela AL, Favarin JL, Fancelli AL, Martin TN, Dourado Neto D \& Reis AR (2006) Doses de nitrogênio e fontes de Cu e Mn suplementar sobre a severidade da ferrugem e atributos morfológicos do milho. Revista Brasileira de Milho e Sorgo, 5:192-201.

Tutida I, May-De Mio LL, Motta ACV \& Rosa JMC (2007) Incidência e severidade do "furo de bala" em folhas da ameixeira sob doses de nitrogênio e potássio. Ciência Rural, 37:1227-1234.
Vaz-de-Melo A, Afférri FS, Dotto MA, Peluzio JM, Santos GR \& Carvalho EV (2010) Reação de híbridos de milho à Curvularia ssp sob dois níveis de adubação com nitrogênio no sul do Tocantins. Scientia Agrária, 11:149-154. 